\title{
The potential of "umbuzeiro" genotypes for the development of preserves
}

\author{
Renata Torres dos Santos e Santos ${ }^{1 *}$ Carlos Antônio Fernandes Santos ${ }^{2}$ \\ Viseldo Ribeiro de Oliveira ${ }^{2}$ Saulo de Tarso Aidar ${ }^{2}$ Ana Cecília Poloni Rybka ${ }^{2}$ (D) \\ Clívia Danúbia Pinho da Costa Castro ${ }^{(1 D}$ Aline Camarão Telles Biasoto ${ }^{2}$ (iD
}

\begin{abstract}
${ }^{1}$ Programa de Pós-graduação em Ciência de Alimentos, Universidade Federal da Bahia (UFBA), 40170-115, Salvador, BA, Brasil. E-mail: retorressantos@gmail.com. "Correspondig author.

${ }^{2}$ Empresa Brasileira de Pesquisa Agropecuária (Embrapa), Petrolina, PE, Brasil.

ABSTRACT: One of the relevant economic importances of the "umbuzeiro" (Spondias tuberosa Arruda) to the northeastern semiarid region of Brazil is the fruit processing to obtaining preserves. However, there are limitations in the production and standardization of this product, such as color, taste and texture, which are problems in the quality, identity, making it harder to achieve new markets. This study was carried out aiming to evaluate the potential of "umbu" genotypes (Access 37, Access 44, BRS 48, BRS 52, BRS 55 and BRS 68) registered by Embrapa in the development of preserves. It was evaluated the product $p H$, total acidity, water activity, soluble solids, moisture, firmness, color ( $L^{*}$, $a^{*}$, $\left.b^{*}\right)$, reducing and non-reducing sugars, vitamin $C$, syneresis and consumer acceptance regarding the overall impression. The CATA method was applied to describe the sensorial profile of the samples. According to the results, it was observed a significant difference (p $\leq 0.05)$ in the physico-chemical composition of the samples, being samples produced from the access 37 and BRS 68 more appropriated for processing of preserves (in bars), with greater firmness and less syneresis. Consumers indicated products from the genotypes 37, 44, BRS 52 and BRS 55 as the ones with highest acceptance regarding the overall impression; the consumers associated the samples in different characterizations, associating the access 37 and BRS 68 with the characteristics of firm and delicious; the commercial sample was characterized as acid, adstringent and terrible.
\end{abstract}

Key words: Spondias tuberosa, Caatinga biome, CATA-Check-all-that-apply.

Potencial de genótipos de umbuzeiro para o desenvolvimento de doce em massa

RESUMO: Uma das relevantes importâncias econômicas do umbuzeiro (Spondias tuberosa Arruda) ao semiárido nordestino pode ser atribuída ao beneficiamento do fruto na forma do tradicional doce em massa. Entretanto, existem limitações na produção e padronização deste derivado quanto sua cor, sabor e textura, o que prejudica sua qualidade, identidade e alcance de outros mercados. Este trabalho foi conduzido buscando analisar o potencial de genótipos de umbu (Acesso 37, Acesso 44, BRS 48, BRS 52, BRS 55 e BRS 68), registrados pela Embrapa, para o desenvolvimento de doce em massa. Avaliou-se a qualidade dos produtos obtidos, diante de uma amostra comercial, quanto a composição físico-química ( $\mathrm{pH}$, acidez total, atividade de água, sólidos solúveis, umidade, firmeza, cor $\left(L^{*}, a^{*}, b^{*}\right)$, açúcares redutores e não-redutores, vitamina $C$ e sinérese) e aceitação por consumidores quanto a impressão global. O método CATA foi aplicado para descrever o perfil sensorial das amostras. Os resultados mostraram diferença significativa ( $\leq \leq 0.05)$ na composição fisico-química das amostras, sendo as amostras Acesso 37 e BRS 68 as mais apropriados ao processamento de doce em massa, com a maior firmeza e menor sinérese. Os consumidores indicaram os genótipos 37, 44, BRS 52 e BRS 55 com maiores médias de aceitação na impressão global; associaram as amostras em distintas caracterizações, indicando o Acesso 37 e BRS 68 como mais gostosos e firmes, e a amostra comercial como a mais ácida, adstringente e terrivel.

Palavras-chave: Spondias tuberosa, bioma Caatinga, CATA-Check-all-that-apply.

\section{INTRODUCTION}

The Spondias tuberosa Arruda, known as "umbuzeiro", belongs to the Anacardiaceae family and is a tropical fruit tree, native to semiarid regions of the Brazilian northeast region, with high genetic diversity in the regions kwown as Agreste, Cariri and Caatinga (SANTOS et al., 2008).

Is a species of great importance for the Caatinga biome, being considered a vegetal product of extractivism with a significant secular role for the family income of the brazillian semiarid Northeastern population, due to its adaptation to the extreme climatic conditions of the region, such as high temperatures and lack of water (SANTOS et al., 2008).

However, over the last few years, some studies have reported that the production generated by the extractive activity of umbuzeiro fruits has declined, which may be related to the reduction of the natural populations, with a consequent risk of extinction (SANTOS et al., 2005). In this context, aiming the formation of areas with higher income 
generation potential, the cultivation of genotypes with superior and stable characteristics of fruit production is presented as an alternative to ensure the continuity of the fruit supply, also reducing the pressure of the extractivism on the natural populations of the species (ARAUJO, 2014; ARAUJO et al., 2016). The cultivation of genotypes that present desirable characteristics and higher yield represents an important alternative for the São Francisco Valley growers.

Its fruit, known as umbu, imbu or ambu, is a glabrous or lightly pilose drupe, with a smooth surface or with 4 to 5 small protuberances in the distal portion, presenting a rounded shape, ranging from $3-4 \mathrm{~cm}$ in length, 2-4 cm of diameter, and 8-23 g of mass; with $22 \%$ of the weight in skin, $68 \%$ of flesh and $10 \%$ is the seed (NARAIN et al., 1992). Its pulp present $\mathrm{pH}$ around 2.5 , acidity of $1.4 \%$ (in citric acid), pectin content of $1.0 \%$ and vitamin C of $24.97 \mathrm{mg} / 100 \mathrm{~g}$ of pulp (PAULA et al., 2012). At the beginning of maturation, the skin is green in color and when ripe, greenish yellow and the greenish-white, soft, juicy pulp with an exotic and sweet-sour taste, presenting soluble solids content around $9.5^{\circ}$ Brix (GALVÃO et al. al., 2011).

Considering the significant commercial value of umbu for the domestic market and, in particular, for industrialization, the expansion of commercialization of fruits for 'in natura' consumption and its processing through pulps, jellies, preserves, ice cream and beverages, from an estimated harvest of 7,765 tons (IBGE, 2018), indicates a very promising market for this species endemic to the Caatinga biome. In this scenario, the State of Bahia is the largest national producer, with production of 5,752 tons in 2018, according to IBGE.

Among the umbu products, the preserve in bars is very popular and with high consumption in the Northeast region of the Brazil. It is characterized as the product resulting from the proper processing of the disintegrated edible parts of vegetables with sugar, with or without added water, pectin ( 0.5 to $1.5 \%$ in relation to pulp), $\mathrm{pH}$ adjustor (in sufficient amount to the achieve 3 to 3.4 in $\mathrm{pH}$ ) and other ingredients and additives allowed by these standards until a consistency of gelatinization, being finally conditioned in order to ensure its perfect conservation (GAVA et al, 2009).

Therefore, the development of an appropriate technology for the elaboration of preserves aims to take advantage of the integral production of the fruit, minimizing the postharvest losses, besides adding value to the product, contributing to the strengthening of family farming and regional development (MARTINS et al., 2007).
In this way, this study was conducted with the objective of analyzing the viability of the use of umbu genotypes of the Germoplasm Bank, for processing in the form of preserves (in bars).

\section{MATERIALS AND METHODS}

For the preparation of the umbu preserve, the highly productive umbu genotypes were used during the 2017 harvest, correspond as varieties BRS 48, BRS 52, BRS 55 and BRS 68 and the Access 37 and 44 . These genotypes were developed by the breeding program of Embrapa (Petrolina-PE, Brazil) (OLIVEIRA et al., 2016). Four of these genotypes were registred in 2019 as new umbu varieties. The fruits were manually harvested from the Embrapa Semiarid Experimental Field (coordinates 0904'16.4 "S, $040^{\circ} 19^{\prime} 5.37$ " W, Petrolina / PE, Brazil) at the intermediate stage of maturation. The fruits were visually selected in this maturation stage according to firmness and the green skin color. Fruit were stored for three days after harvesting at a temperature of $28 \pm 2{ }^{\circ} \mathrm{C}$, until they softened and the skin reached a yellowish color.

Fruits were washed in running water, immersed in sodium hypochlorite solution at 200 $\mathrm{mg} \mathrm{L}^{-1}$ for $15 \mathrm{~min}$ and rinsed in running water, and then the fruits with the peel were pulped in an electric fruit stripper (Macanuda, model DMJI-05, Brazilian Industry) in a 10 mesh sieve.

For processing, the pulp of the umbu genotype was submitted to heating in stainless steel pan under atmospheric pressure and constant manual stirring until the soluble solids content of $75^{\circ}$ Brix. Pulps were prepared in duplicates from the same formulation, using $49 \%$ of umbu pulp of each access, $50 \%$ of sucrose (crystal sugar, brand Primavera, Pernambuco, Brazil) and $1 \%$ of pectin (Mago, São Paulo, Brazil). Prior to processing, the $\mathrm{pH}$ of the pulp was corrected to 3.2 with the addition of calcium carbonate. The sugar and the pectin were added to the processing only when the umbu pulp achieved $65^{\circ} \mathrm{C}$. The preserves were hot-packaged in polypropylene packages, cooled with water (room temperature, $\left.22 \pm 2{ }^{\circ} \mathrm{C}\right)$ and stored under refrigeration $\left(7{ }^{\circ} \mathrm{C}\right)$ for subsequent physic-chemical and sensorial analyzes.

The comercial sample of the umbu preserve was purchased directly from the largest cooperative located in the semiarid region of the Bahia State (with more than 270 cooperates), which was processed from the pulp obtained from native fruits of the Caatinga biome. The commercial umbu preserve (in mass) was produced by heating the "in natura" fruit, as is 
done by most agro-industries in the semiarid region of Northeast Brazil. When preparing the sweet, water is added to cook the fruits, and then, after pulping, sugar and citric acid (optional ingredient) are added to the cooked pulp.

The pulps of the umbu genotypes (Acess 37,44 , BRS 48, 52, 55 and 68), the umbu preserves obtained from these genotypes and the commercial preserve, were characterized according to: $\mathrm{pH}$, by the direct reading of the samples in $\mathrm{pH}$ meter (Hanna Instruments, model HI 2221); titratable acidity (expressed as citric acid) by the titration with $0.1 \mathrm{M}$ of $\mathrm{NaOH}$ solution in automatic titrator (Metrohm, model Tritino Plus 848, Switzerland - Switzerland); soluble solids (SS) using direct reading of the sample in portable refractometer (Atago, Pocket Refractometer PAL-3 model); total and reducing sugars, by the Lane Eynon method and titration with Fehling reagent A and $\mathrm{B}$ (AOAC, 2012); color, through the direct reading of the parameters $\mathrm{L}^{*}$ [white $(0)$ to black (100)], a* [red $(+)$ to green $(-)$ ] and $\mathrm{b}^{*}[$ yellow $(+)$ to blue $(-)]$, through the CIELab color system in a portable colorimeter (Konica Minolta brand, model CR-400); and vitamin $\mathrm{C}$, using titration with 2,6-dichloro-phenol indophenol solution (STROHECKER \& HENNING, 1967). Some physico-chemical parameters were only analyzed in the umbu preserves, such as: water activity (Aw), in Aw meter (Decagon, model PawKit Acqualab) at $25^{\circ} \mathrm{C}$ (AOAC, 2012); moisture, on a moisture-determining scale with infrared heating system at $105^{\circ} \mathrm{C}$ (Moisture Analyzer, MX-50); firmness, by evaluating of the force in texturometer (Stable Micro Systmes, Surrey, UK), based on MARTINS et al. (2007); and syneresis, from the analysis of the exudates of the preserves placed in plastic collectors (internal area $25.12 \mathrm{~cm}^{2}$ ), and with quantitative filter paper (ø $12.5 \mathrm{~cm}$ and thickness of $0.20 \mathrm{~mm})$, previously dried in an oven $\left(105^{\circ} \mathrm{C}\right.$ for $24 \mathrm{~h}$ ), using the procedure described by FISZMAN \& DURÁN (1992) and the Image J software, version $1.51 \mathrm{p}$, for the areas calculation. Additionally, soluble pectin was determined in the fruit pulps, by the UV spectrometer $(520 \mathrm{~nm})$ using the m-hydroxydiphenyl method (McREADY \& MacCOMB, 1952).

Habitual consumers of umbu were invited to participate of the sensory evaluation of the comercial and from genotypes umbu preserves. One hundred and twelve volunteers were selected, being 71 women and 41 men, with ages ranging from 17 and 66 years old. All the consumers evaluated the overall acceptability of the umbu preserves using the traditional nine-points hedonic scale $(1=$ "disliked extremely"; 9 = "liked extremely"). The seven samples were presented in a single session in monadic form of presentation. In order to avoid tiredness and sensory fatigue, water and water biscuit without salt, were served to the consumers during samples evaluations. Additionally, a 20 minutes interval was given between the evaluation of the first four samples and the last three. The samples were evaluated one at a time, in $5 \mathrm{~g}$ cubes at room temperature, placed in $50 \mathrm{~mL}$ disposable cups coded with three digit code. The order of the samples presentation among the participants followed the complete balanced block design proposed by MACFIE et al. (1989). In the same evaluation session, the CATA - Check-all-that-apply method (ARES et al., 2014) was used to describe the sensory profile of the products by consumers, from a questionnaire containing 23 previously selected terms by a focus group. The consumers were instructed to indicate by marking with an ' $x$ ' the terms of the questionnaire that they judge that characterized each sample. The terms of the CATA included 23 sensory characteristics related to the appearance, aroma, flavor and texture of samples, such as: atractive color, bright, brow-yellowish color, brown-greenish color, brownredish color, brown-dark color, opaque color, caramel aroma, "umbu" aroma, sweet aroma, burned aroma, sweetness, sourness, "umbu" flavor, fibrous residual, stick, creamy, soft, firm, adstringent, tasty, cloying and terrible. The sensorial test was conducted in individual booths, under white light and with temperature control $23 \pm 1{ }^{\circ} \mathrm{C}$ in the Laboratory of Sensory Analysis of Embrapa (Petrolina, PE, Brazil) and at the Federal University of Bahia (Salvador, BA, Brazil).

Results of the physico-chemical analysis and the sensory acceptance test were submitted to ANOVA and Tukey's mean test $(\mathrm{p} \leq 0.05)$ using the statistical software Statistical Analytical Systems - SAS (SAS Institute, Cary, NC, USA, University Edition, 2017). The CATA results were analyzed by the XLStat software (Addinsoft Inc., Anglesey, UK, 2015). As the CATA responses to each term is binary ( $1=$ term marked by the consumer; $0=$ term not marked by the consumer), was used nonparametric Cochran's Q Test $(\mathrm{p} \leq 0.05)$ and comparisons based on the Marascuilo approach. Additionaly, in order to get a bi-dimensional representation of the samples, Correspondence Analysis (CA) was perfomed to identify differences and similarities among the samples. Using the XLStat software, Internal Preference Mapping - MDPREF (MACFIE \& THOMSON, 1988) was constructed through the Principal Component Analysis and Pearson correlation matrix to confirm the consumer's preference using the overall acceptance data of the samples of umbu 
preserve. Partial Least Squares Regression (PLS) was also generated to correlate the physico-chemical variables with the overall acceptance at a $5 \%$ level of significance (BIASOTO et al., 2014).

\section{RESULTS AND DISCUSSION}

The pulp of the umbu genotypes showed diferent compostion (Table 1). The $\mathrm{pH}$ ranged from 2.34 to 2.42 , titratable total acidity (expressed in citric acid) among 1.26 and $1.36 \%$, soluble solids of 9.37 to $10.40^{\circ}$ Brix, reducing sugars (expressed in glucose) between 3.7 and $3.9 \%$, vitamin $\mathrm{C}$ among

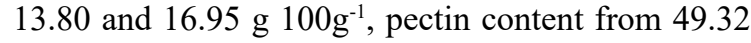

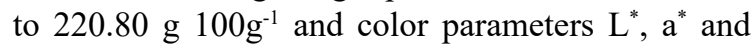
$\mathrm{b}^{*}$ varied of 45.18 to $50.88,-1.39$ to 1.95 , and 18.36 to 22.62 , respectively. The results found are close to those found in the literature for the evaluation of native umbu fruit (FERREIRA et al., 2010; GALVÃO et al. al., 2011; PAULA et al., 2012). However, the umbu genotypes stand out from the native fruit for presenting higher levels of soluble solids and better desirable characteristics by the processing, with fruits weighing over of $20 \mathrm{~g}$, with thin and smooth peel, and a higher percentage of pulp (MACHADO \& FONSECA, 2010).

The physico-chemical composition of umbu preserves from Embrapa Tropical Semi-Arid Germplasm Bank, Petrolina - PE, Brazil (Access 37,44 , and varieties BRS 48, 52, 55, 68), can be found in Table 2 . There was a significant difference $(p \leq 0.05)$ between the studied samples for all evaluated variables (Table 2). Although, the umbu preserves have been made with the same formulation and processing conditions, it was not possible to guarantee similar physico-chemical characteristics among the samples. The figure 1 also illustrate the different characteristics between the umbu fruits, pulps and preserves. Thus, the processing time for each preserve until the achievement of $75^{\circ}$ Brix was different according to the umbu genotype.

The umbu preserves elaborated with the six genotypes presented a variation in $\mathrm{pH}$ from 3.50 (BRS 68) to 3.82 (Access 44), while the value of $\mathrm{pH}$ of the commercial product was 2.41. Conversely, the comercial preserve presented a higher titratable acidity (TA), of $2.27 \%$, and the TA values of the preserves from the genotypes varied between 0.68 and $0.81 \%$ (Access 37 and BRS 48, respectively). MARTINS et al. (2010) elaborated umbu preserves from fruits in the green and ripe stages, and obtained $\mathrm{pH}$ and acidity in the range of 3.33 to 3.83 and 0.32 to $0.66 \%$, respectively. The values reported by the cited authors were similar for $\mathrm{pH}$ and lower for acidity. The significant difference $(\mathrm{p} \leq 0.05)$ between the $\mathrm{pH}$ and TA values of the commercial samples and of the samples obtained from the umbu genotypes can be explained by the addition of citric acid to the commercial formulation, as stated on the product packaging as an item in the list of ingredients.

Considering the different samples from different genotypes and commercial preserve, it was observed a soluble solids (SS) content of

Table 1 - Pulp physico-chemical composition of "umbu" genotypes.

\begin{tabular}{|c|c|c|c|c|c|c|}
\hline \multirow[t]{2}{*}{ Physico-chemical variables ${ }^{2}$} & \multicolumn{6}{|c|}{ 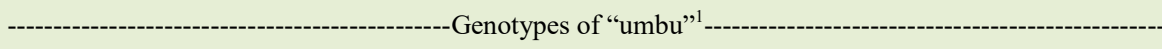 } \\
\hline & Access 37 & Access 44 & BRS 48 & BRS 52 & BRS 55 & BRS 68 \\
\hline $\mathrm{pH}$ & $2.42 \pm 0.01$ & $2.38 \pm 0.02$ & $2.34 \pm 0.01$ & $2.36 \pm 0.01$ & $2.35 \pm 0.01$ & $2.41 \pm 0.01$ \\
\hline Titurable acidity & $1.34 \pm 0.07$ & $1.32 \pm 0.03$ & $1.36 \pm 0.01$ & $1.27 \pm 0.01$ & $1.26 \pm 0.01$ & $1.33 \pm 0.01$ \\
\hline Soluble solids & $9.47 \pm 0.2$ & $10.07 \pm 0.06$ & $9.37 \pm 0.01$ & $9.73 \pm 0.06$ & $9.73 \pm 0.06$ & $10.40 \pm 0.00$ \\
\hline Reducing sugars & $37.79 \pm 0.1$ & $39.70 \pm 0.03$ & $38.40 \pm 0.08$ & $39.45 \pm 0.06$ & $38.95 \pm 0.1$ & $39.39 \pm 0.05$ \\
\hline Ascorbic acid & $16.95 \pm 0.5$ & $13.80 \pm 0.8$ & $15.52 \pm 0.8$ & $15.80 \pm 0.5$ & $16.09 \pm 0.5$ & $16.95 \pm 0.5$ \\
\hline Pectin & $119.01 \pm 0.02$ & $92.35 \pm 0.02$ & $52.25 \pm 0.04$ & $162.64 \pm 0.02$ & $49.32 \pm 0.04$ & $220.81 \pm 0.04$ \\
\hline Parameter color $\mathrm{L}^{*}$ & $46.95 \pm 0.5$ & $45.18 \pm 0.2$ & $46.48 \pm 0.3$ & $50.59 \pm 0.5$ & $50.88 \pm 0.5$ & $47.49 \pm 0.3$ \\
\hline Parameter color $\mathrm{a}^{*}$ & $-1.39 \pm 0.05$ & $-0.83 \pm 0.01$ & $0.05 \pm 0.02$ & $-0.56 \pm 0.02$ & $-0.23 \pm 0.01$ & $1.95 \pm 0.03$ \\
\hline Parameter color $\mathrm{b}^{*}$ & $22.62 \pm 0.07$ & $18.52 \pm 0.04$ & $18.36 \pm 0.04$ & $22.28 \pm 0.03$ & $21.40 \pm 0.02$ & $20.79 \pm 0.05$ \\
\hline
\end{tabular}

${ }^{(1)}$ Means \pm standard deviation $(n=3) .{ }^{(2)}$ Titratable Acidity in \% citric acid, Soluble solids in ${ }^{\circ}$ Brix, Reducing sugars in $\%$ sucrose, Ascorbic acid in $\mathrm{mg} 100 \mathrm{~g}^{-1}$, Pectin in $\mathrm{mg} 100 \mathrm{~g}^{-1}, \mathrm{~L}^{*}$ : write $(0)$ to black $(100), \mathrm{a}^{*}$ : red $(+)$ to green $(-), \mathrm{b}^{*}:$ yellow $(+)$ to blue $(-)$. 
Table 2 - Physico-chemical composition of umbu preserves.

\begin{tabular}{|c|c|c|c|c|c|}
\hline \multirow[t]{2}{*}{$\begin{array}{l}\text { Samples of "umbu" } \\
\text { 'preserves } 1\end{array}$} & \multicolumn{5}{|c|}{ 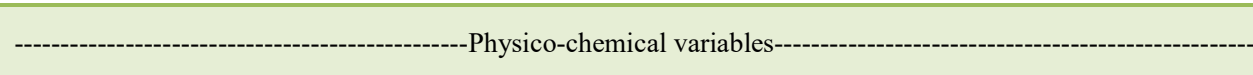 } \\
\hline & $\mathrm{pH}$ & TA ( $\%$ citric acid $)$ & SS ( ${ }^{\circ}$ Brix $)$ & Aw $(\%)$ & Moisture (\%) \\
\hline Access 37 & $3.74 \pm 0.05 \mathrm{ab}$ & $0.68 \pm 0.06 \mathrm{~d}$ & $76.15 \pm 1.42 \mathrm{a}$ & $0.66 \pm 0.02 \mathrm{ab}$ & $12.38 \pm 1.03 \mathrm{c}$ \\
\hline Access 44 & $3.82 \pm 0.02 \mathrm{a}$ & $0.69 \pm 0.01 \mathrm{~d}$ & $76.13 \pm 0.96 \mathrm{a}$ & $0.65 \pm 0.02 \mathrm{bc}$ & $11.71 \pm 1.01 \mathrm{c}$ \\
\hline BRS 48 & $3.55 \pm 0.04 \mathrm{c}$ & $0.81 \pm 0.01 \mathrm{~b}$ & $75.40 \pm 0.47 \mathrm{a}$ & $0.67 \pm 0.02 \mathrm{ab}$ & $17.55 \pm 1.89 \mathrm{ab}$ \\
\hline BRS 52 & $3.73 \pm 0.04 \mathrm{ab}$ & $0.71 \pm 0.03 \mathrm{~cd}$ & $75.43 \pm 0.20 \mathrm{a}$ & $0.62 \pm 0.00 \mathrm{c}$ & $14.50 \pm 1.47 \mathrm{bc}$ \\
\hline BRS 55 & $3.71 \pm 0.08 \mathrm{~b}$ & $0.78 \pm 0.02 \mathrm{cb}$ & $75.43 \pm 0.96 a$ & $0.63 \pm 0.02 \mathrm{c}$ & $14.94 \pm 1.52 b c$ \\
\hline BRS 68 & $3.50 \pm 0.04 \mathrm{c}$ & $0.80 \pm 0.03 \mathrm{cb}$ & $75.42 \pm 0.58 \mathrm{a}$ & $0.68 \pm 0.01 \mathrm{a}$ & $16.55 \pm 1.15 \mathrm{ab}$ \\
\hline Commercial & $2.41 \pm 0.09 \mathrm{~d}$ & $2.27 \pm 0.11 \mathrm{a}$ & $72.73 \pm 2.63 b$ & $0.62 \pm 0.02 \mathrm{c}$ & $19.27 \pm 4.51 \mathrm{a}$ \\
\hline \multicolumn{6}{|l|}{$\begin{array}{l}\text { Samples of "umbu" } \\
\text { preserves }\end{array}$} \\
\hline & Firmness (N) & $\min C(\operatorname{mg} 100 \mathrm{~g}-1)$ & RS (\%) & NRS (\%) & Total sugars $(\%)$ \\
\hline Access 37 & $1.37 \pm 0.08 \mathrm{~b}$ & $16.81 \pm 0.47 \mathrm{a}$ & $25.91 \pm 1.43 \mathrm{c}$ & $22.99 \pm 1.37 \mathrm{c}$ & $48.89 \pm 2.80 \mathrm{c}$ \\
\hline Access 44 & $0.59 \pm 0.01 \mathrm{~cd}$ & $13.22 \pm 0.45 \mathrm{~d}$ & $26.37 \pm 2.08 \mathrm{c}$ & $22.94 \pm 2.18 \mathrm{c}$ & $49.32 \pm 4.25 c$ \\
\hline BRS 48 & $0.20 \pm 0.00 \mathrm{~d}$ & $15.08 \pm 0.47 \mathrm{c}$ & $26.01 \pm 0.57 \mathrm{c}$ & $23.16 \pm 0.57 \mathrm{c}$ & $49.17 \pm 1.15 \mathrm{c}$ \\
\hline BRS 52 & $0.69 \pm 0.01 \mathrm{~cd}$ & $15.23 \pm 0.45 \mathrm{bc}$ & $29.81 \pm 1.30 \mathrm{~b}$ & $26.30 \pm 1.36 b$ & $56.11 \pm 2.64 b$ \\
\hline BRS 55 & $0.30 \pm 0.01 \mathrm{~d}$ & $15.95 \pm 0.47 \mathrm{~b}$ & $27.13 \pm 1.28 \mathrm{c}$ & $24.02 \pm 1.27 \mathrm{bc}$ & $51.15 \pm 2.55 \mathrm{c}$ \\
\hline BRS 68 & $0.98 \pm 0.01 \mathrm{c}$ & $16.81 \pm 0.47 \mathrm{a}$ & $19.42 \pm 0.57 \mathrm{~d}$ & $16.75 \pm 0.54 \mathrm{~d}$ & $36.17 \pm 1.11 \mathrm{c}$ \\
\hline Commercial & $3.43 \pm 0.05 \mathrm{a}$ & $15.95 \pm 0.47 \mathrm{~b}$ & $38.01 \pm 0.93 \mathrm{a}$ & $34.06 \pm 0.94 \mathrm{a}$ & $72.20 \pm 1.87 \mathrm{a}$ \\
\hline \multicolumn{6}{|l|}{$\begin{array}{l}\text { Samples of "umbu" } \\
\text { 'preserves } 1\end{array}$} \\
\hline & Color parameter $\mathrm{L}^{*}$ & Color parameter $\mathrm{a}^{*}$ & Color parameter $\mathrm{b}^{*}$ & \multicolumn{2}{|c|}{ Syneresis $\left(\mathrm{cm}^{2}\right)$} \\
\hline Access 37 & $22.90 \pm 0.71 \mathrm{~cd}$ & $-0.38 \pm 0.15 \mathrm{e}$ & $3.97 \pm 0.39 \mathrm{~cd}$ & \multicolumn{2}{|c|}{$20.33 \pm 16.39 b c$} \\
\hline Access 44 & $26.05 \pm 1.65 \mathrm{abc}$ & $4.93 \pm 1.21^{\mathrm{a}}$ & $7.36 \pm 1.50 \mathrm{a}$ & \multicolumn{2}{|c|}{$32.24 \pm 7.21 \mathrm{ab}$} \\
\hline BRS 48 & $29.20 \pm 1.48 \mathrm{a}$ & $0.29 \pm 0.31 \mathrm{cde}$ & $5.05 \pm 0.73 b c$ & \multicolumn{2}{|c|}{$35.95 \pm 7.97 \mathrm{a}$} \\
\hline BRS 52 & $25.44 \pm 1.71 \mathrm{c}$ & $0.55 \pm 0.09 \mathrm{~cd}$ & $4.10 \pm 0.63 \mathrm{~cd}$ & \multicolumn{2}{|c|}{$31.41 \pm 1.48 \mathrm{ab}$} \\
\hline BRS 55 & $23.65 \pm 2.71 \mathrm{~cd}$ & $1.76 \pm 0.17 b$ & $2.97 \pm 0.47 \mathrm{~cd}$ & \multicolumn{2}{|c|}{$45.32 \pm 7.06 \mathrm{a}$} \\
\hline BRS 68 & $28.30 \pm 3.42 \mathrm{ab}$ & $0.19 \pm 0.27 \mathrm{de}$ & $6.96 \pm 2.51 \mathrm{ab}$ & \multicolumn{2}{|c|}{$5.49 \pm 4.42 \mathrm{c}$} \\
\hline Commercial & $21.15 \pm 0.91 \mathrm{~d}$ & $1.04 \pm 0.18 b c$ & $2.24 \pm 0.51 \mathrm{~d}$ & \multicolumn{2}{|c|}{$31.59 \pm 3.37 \mathrm{ab}$} \\
\hline
\end{tabular}

(1) Means \pm standard deviation, followed by the same letters in the column are not different according to the Tukey's means test ( $\mathrm{p}>0.05$ ). $\mathrm{TA}=$ Titratable Acidity, $\mathrm{SS}=$ soluble solids, Aw = water activity, RS = Reducing Sugars, NR = Non-reducing Sugars. $\mathrm{L}^{*}:$ write $(0)$ to black (100); $\mathrm{a}^{*}$ : red $(+)$ to green $(-) ; \mathrm{b}^{*}:$ yellow $(+)$ to blue $(-)$

$75^{\circ}$ Brix for preserves from different genotypes, being significantly higher than that observed fot the commercial preserve, which presented SS content of $72.73{ }^{\circ}$ Brix, and for values observed by MARTINS et al. (2010) for preserves with mature umbu $(72.50$ ${ }^{\circ}$ Brix). In addition, it was observed water activity average from 0.62 and 0.68 (Table 2), lower values than the observed by MARTINS et al. (2010), which was 0.74 to 0.82 for preserves from green and ripe umbu fruits, that contribute to extend the shelf life of the product. It should be noticed that these values are probably different due to the differences in the formulation used for the preparation of the preserves and in fruit composition.

The moisture observed (Table 2) ranged from 11.71 to $17.55 \%$ among the preserves using the different fruit genotypes (values of the Access 44 and BRS 48 , respectively), and $19.27 \%$ for the commercial sample. It was observed that the sample with the highest moisture content (comercial umbu preserve) presented the lowest SS concentration, $72.73^{\circ}$ Brix.

It can be observed among the genotyes a variation of firmness (Table 2) when compared 


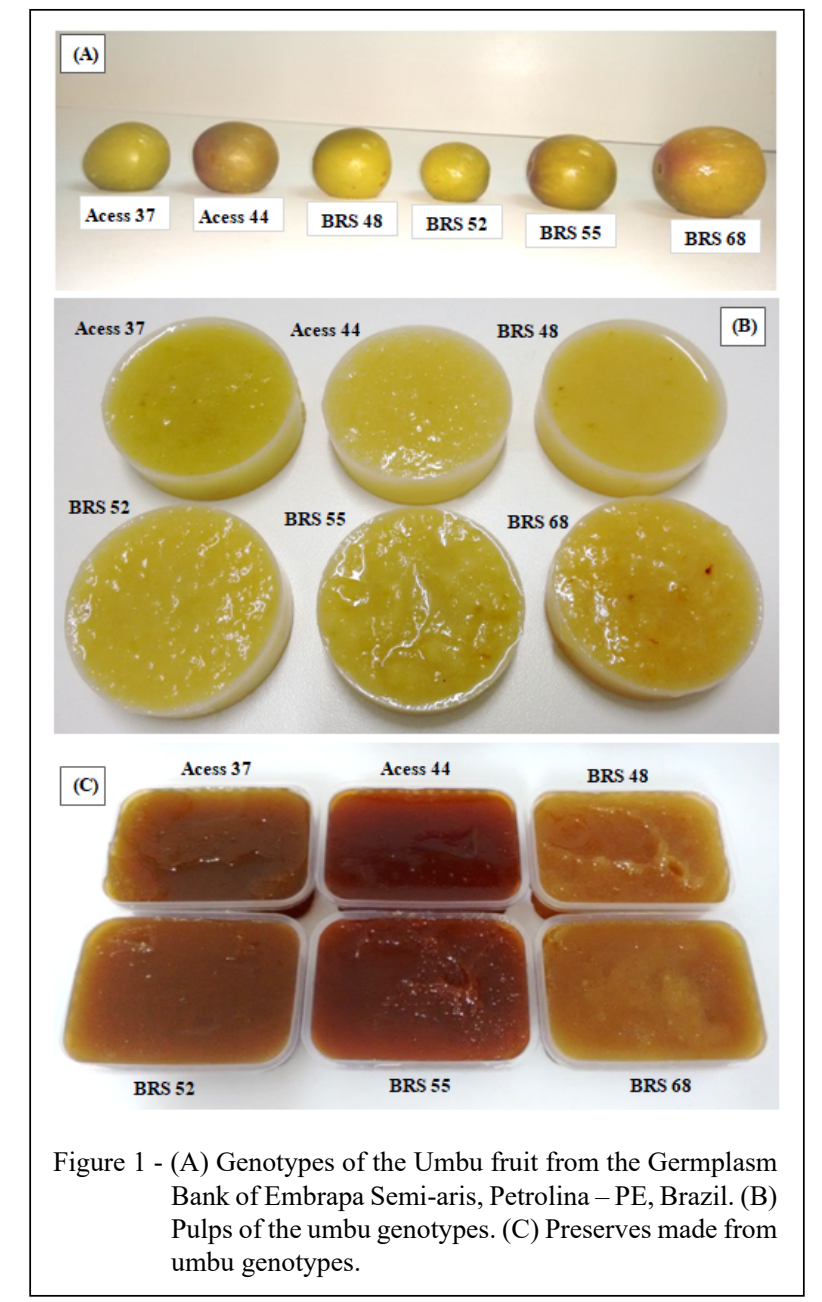

to the SS content, from 0.20 to $1.37 \mathrm{~N}$; while the commercial sample presented firmness of $3.43 \mathrm{~N}$. Considering this study for the processing preserves in bars, it has been found that, among the genotypes, the Access 37 and BRS 68 were more suitable for cutting, as they presented the highest firmness values. In this context, the processing conditions (cooking time and temperature) of each umbu preserve, as well as, the gel formation (firmness) and the final product characteristics, are directly related with the interaction between the contents of soluble solids, pectin and other characteristics of the fruit pulp composition, as organic acids and amount of fibers, that were not evaluated in this study (GODOY et al., 2009). MENEZES et al. (2009) also affirmed, when evaluating the texturometric profile in guava preserves, that the addition of citric acid directly influences the increase of firmness of the products; which are in accordance to the high firmness value observed in the commercial sample $(3.43 \mathrm{~N})$, which presents citric acid in its composition.

For the ascorbic acid content (Vitamin C), the evaluated samples presented 13.22 to 16.81 $\mathrm{mg} 100 \mathrm{~g}^{-1}$ and commercial preserve presented

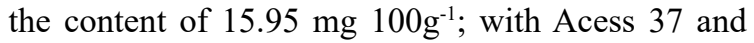
BRS 68 presenting the highest contents, differing significantly $(\mathrm{p} \leq 0.05)$ from the other samples (Table 2 ). In this context, it can be inferred that genotypes with higher content of vitamin $\mathrm{C}$ (Table 1) generated preserves with greater content of ascorbic acid. Additionally, the literature reported different values of ascorbic acid for the native umbu fruit, with ALMEIDA et al. (2011) and RUFINO et al. (2010)

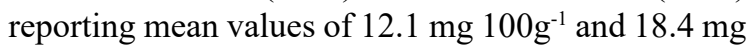
$100 \mathrm{~g}^{-1}$, respectively, being the observed contents in accordance to the cited authors. 
The levels of reducing sugars, expressed as percentage of glucose, were relatively higher than the non-reducing sugars expressed as percentage of sucrose (Table 2) in all samples, meaning that a higher degree of hydrolysis of total sugars occurred during the preserves processing (MENEZES et al., 2009). During the cooking of the preserve, sucrose undergoes an acid hydrolysis process (known as inversion) that partially transforms it into glucose and fructose, which is a necessary and desirable process to avoid crystallization (granulation) in the preserve that may occur during storage. In addition this process can to contribute to increase the firmness of the product (JACKIX, 1988; OLIVEIRA, FEITOSA \& SOUZA, 2018). Prior to the product formulation, the pulp of the umbu genotypes presented 3.7 to $3.9 \%$ of reducing sugars in glucose, as reported by (Table 1). Therefore, it is possible to verify that the commercial sample differed significantly $(p \leq 0.05)$ from the preserves originated from the genotypes, presenting high value of reducing and non-reducing sugars. It is possible that an addition of citric acid increased the reducing sugars content, which may have contributed to increase the firmness of the commercial sample (MENEZES et al., 2009).

Regarding the variable luminosity, $\mathrm{L}^{*}$, it was verified that samples elaborated with the Acess 44 , BRS 48, BRS 52 and BRS 68 presented higher values than the comercial sample, while the preserves from Access 37 and BRS 55 did not differed significantly $(\mathrm{p} \leq 0.05)$ of the commercial sample (Table 2$)$. DIAS et al. (2011) reported that samples with more pectin in their composition presented higher value of the parameter $\mathrm{L}^{*}$ due to the power of the pectin in the gel formation with sugar, forming an amorphous state of jelly, which will present property to reflect part of the incident light, resulting in a whiter appearance to the product. However, assimilation behavior was observed in this study, considering that the BRS 68 presented a greater pectin amounts, followed by the product made with the BRS 52 genotype (Table 1).

For the $\mathrm{a}^{*}$ color parameter, the analyzes indicate that the preserves made from the Access 37 and 44 presented higher negative value $(-0.38)$ and higher positive value (4.93), respectively, and;consequently, are characterized to have the greener (Access 37) and less green and more reddish (Access 44 ) color. In addition, the color parameter $b^{*}$ was higher for the Access 44 (7.36) and lower for the commercial sample (2.24), indicating the intensity of the yellow color in the cited genotype.

It is important to observe that the difference between the preserves color among the umbu genotypes is justified by the composition of the pulps (Table 1). Thus, when compared the color of the preserves of the umbu genotypes with the commercial preserve, the variances among the products also may be explained due to distinct the chemical composition of the native umbu, however the pulp of these fruits was not evaluated. Addictionally, the formation of products derived from enzymatic and non-enzymatic reactions (Maillard reaction, caramelization and vitamin oxidation), during cooking, influenced by the processing conditions and formulation of the product (WICKLUND et al., 2005). POLYCARPO et al. (2007) also points out that, in umbu, chlorophyll and carotenoids are the pigments responsible for the coloring of the fruit, in addition to a small concentration of phenolic compounds, which, according to FENNEMA et al. (2010) and WICKLUND et al. (2005) are degraded by enzymatic and non-enzymatic reactions, influenced by the processing conditions (temperature and cooking time) and formulation $(\mathrm{pH}$, acidity, sugars and pectin), turning into compounds of dark pigments, with brown-greenish color. Thus the difference in the color comparing the commercial sample to the others, can be justified due to the higher cooking time for obtaining the comercial sample when compared to others, since the process of obtaining the pulp used heat and water. The pulp for the preserves of the studied genotypes was obtained with an ain of an electric pulper, without sample heating.

Syneresis is the process of water loss due to exudation during the storage period of the preserves, caused by high acidity and low $\mathrm{pH}$ of the product (MARTINS et al., 2007). In Table 2 was observed a great variation among the umbu preserves between syneresis values, with areas of $5.49 \mathrm{~cm}^{2}$ to $45.32 \mathrm{~cm}^{2}$. For the comercial sample, the syneresis area was $31.59 \mathrm{~cm}^{2}$. It should be noticed that the preserve from the BRS 68 material presented the lowest degree of syneresis $\left(5.49 \mathrm{~cm}^{2}\right)$ and from the BRS 55 the highest $\left(45.32 \mathrm{~cm}^{2}\right)$, which did not differed significantly $(\mathrm{p} \leq 0.05)$ from the Access 44 , BRS 48, BRS 52 and from the commercial product; while the Acess 37 showed syneresis of $20.33 \mathrm{~cm}^{2}$. AGUDELO et al. (2014) and CROPOTOVA et al. (2016) reported in their studies with fruit-filling formulations that the pectin concentration used in the formulation positively influences the degree of syneresis by decreasing it, improving the stability behavior of the gels by acting on the water retention capacity. In fact, BRS 68 and BRS 55 pulps present the highest $\left(220.80 \mathrm{mg} 100 \mathrm{~g}^{-1}\right)$ and lowest $(49.32$ $\mathrm{mg} 100 \mathrm{~g}^{-1}$ ) pectin contents, respectivelly (Table 1 ). Thus, syneresis can be considerd an useful indicator of deterioration of the product during their shelf life, and the umbu fruit from genotype BRS 68 is the most suitable for obtaining the product, followed by Acess 37 . According to the consumers, test, the samples were well accepted. Whose averages of 
overall acceptance have been related to the categories of "like slightly " and " like moderately " of the nine points hedonic scale used. The umbu preserves from the Access 44 and BRS 52 received the highest average of overall aceptance, but with no significant difference $(p>0.05)$ from products obtained from BRS 55, Acess 37 and the commercial sample.

The Internal Preference Mapping MDPREF (Figure 2B), generated according to the consumers responses to the overall acceptance of the evaluated samples (Figura 2A), shows that the first two dimensions explained $54.3 \%$ of the variation occurred in the preference among samples. In the MDPREF, the consumers, who are identified by points, are located close to the samples of their preference. In this way, it is possible to observe that most of the consumers liked better of the product of the genotypes BRS 52, BRS 55, Acess 37 and 44, and were located close to these preserves samples. It is also observed that, although the samples obtained with the cultivars BRS 48 and BRS 68 presented the lowest averages of acceptance (Figure $2 \mathrm{~A}$ ), these also

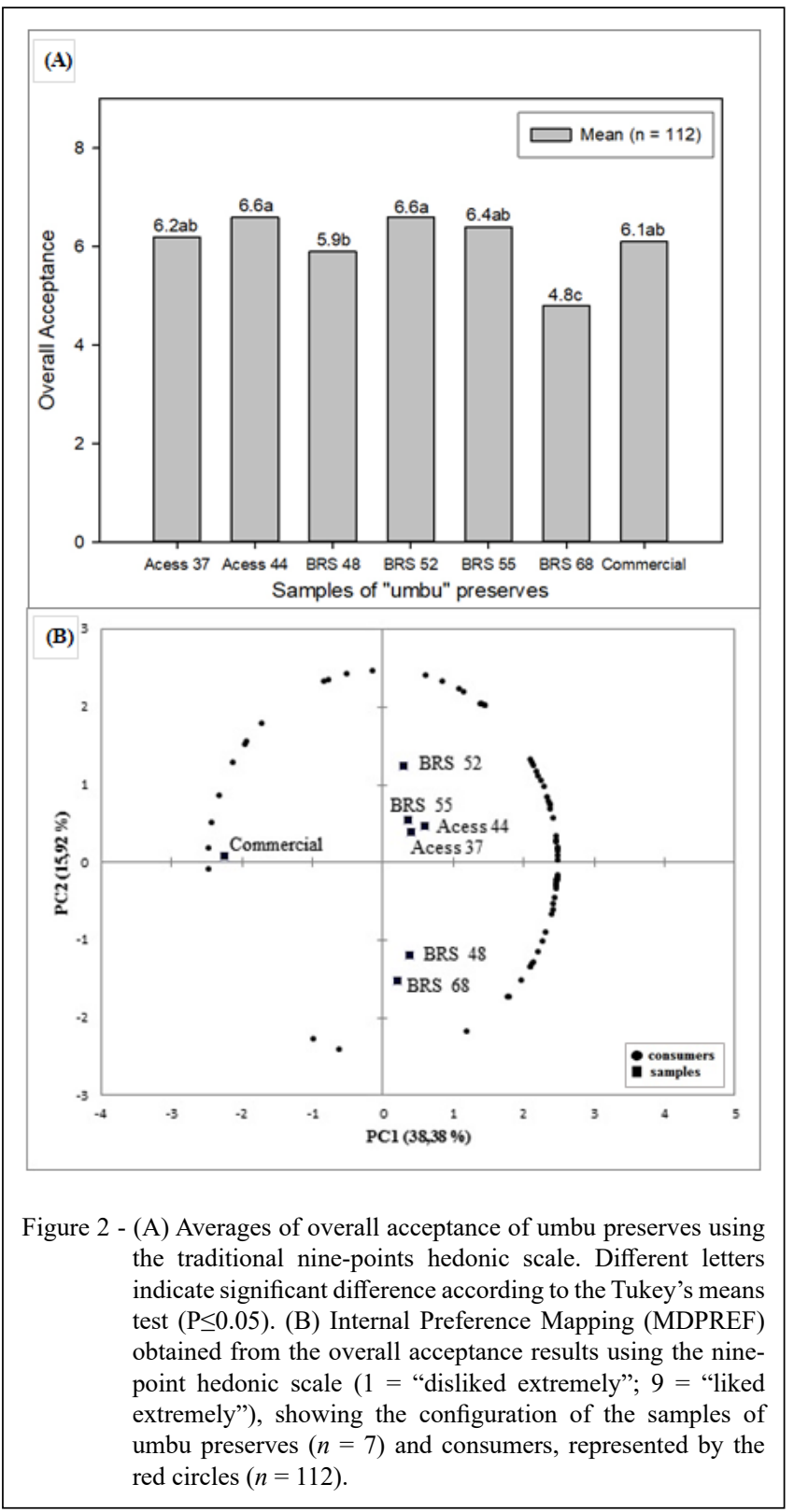

Ciência Rural, v.51, n.2, 2021. 
were prefered by a relevant number of consumers, according to the MDPREF (Figure 2B). In sequence, other group of consumers preferred the commercial umbu preserve, assigning satisfactory acceptance note to it. On the other hand, in the MDPREF, the preserves of the genotypes Acess 37, Acess 44, BRS 52 and BRS 55 are in the opposite position by the PC
1 in relation to the commercial sample, demonstrating a segmentation in the preference of the consumers.

The Partial Least Squares (PLS) regression model was performed to correlate the physicochemical variables with the overall acceptance of the umbu preserves (BIASOTO et al., 2014), as shown in figure 3 . Figure $3 \mathrm{~A}$ shows that only $\mathrm{pH}$

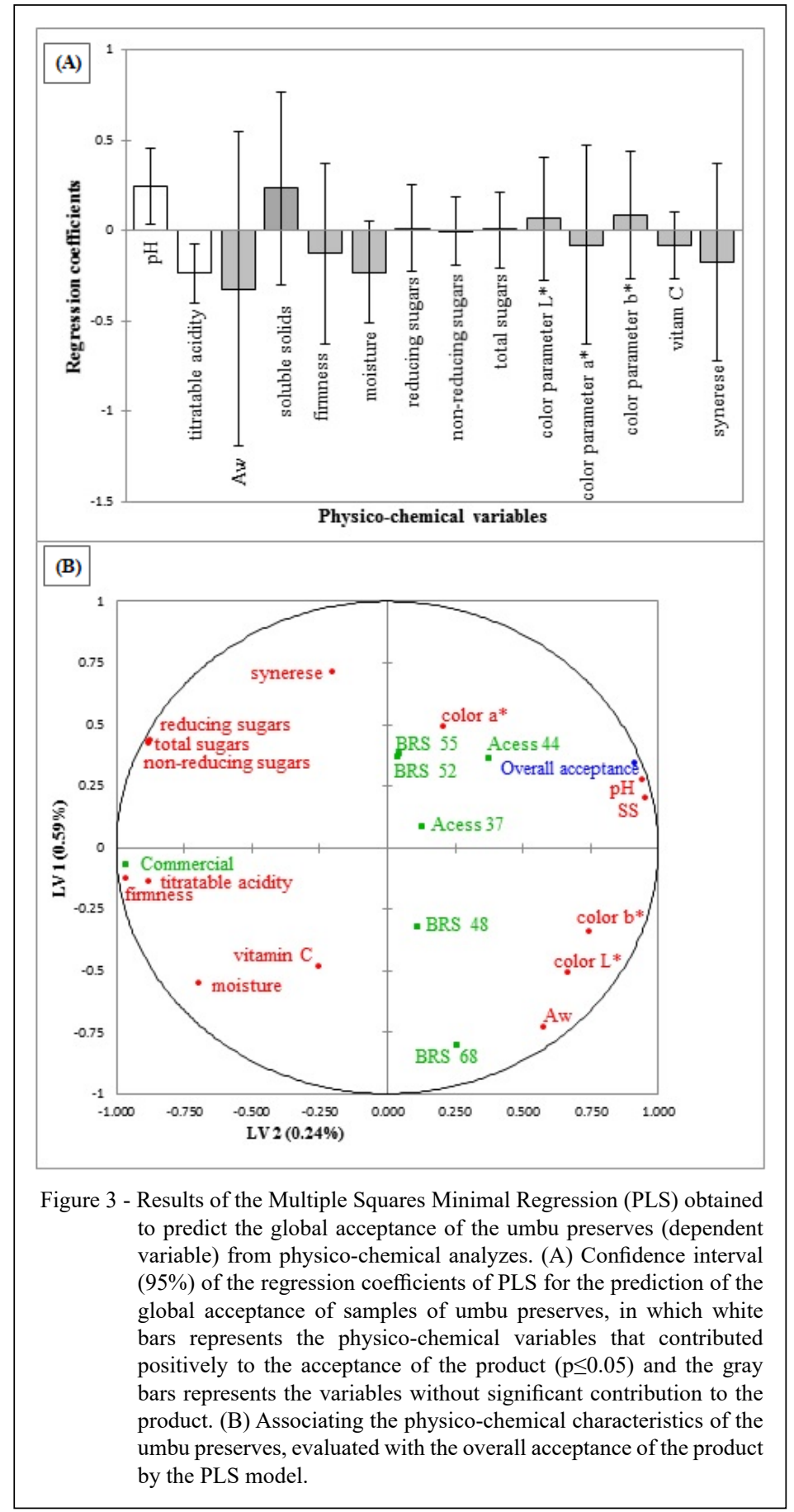

Ciência Rural, v.51, n.2, 2021. 
and titratable acidity were significant $(\mathrm{p} \leq 0.05)$, with a $95 \%$ confidence interval, in the prediction of the overall acceptance of the umbu preserves. This graph exemplifies that the higher the $\mathrm{pH}$ value, the higher the sensory acceptance of the product and, conversely, the higher the titratable acidity content, it is observed lower acceptance. In addition, the PLS model (Figure 3B) showed the distribution of preserves samples by the association of physico-chemical characteristics with the overall acceptance of the product. Thus, the samples BRS 55, BRS 52, Acess 37 and Acess 44 are close to each other and to the vector that represents the overall acceptance, as well as the physico-chemical variable $\mathrm{pH}$, soluble solids and color a*; while BRS 48 and BRS 68 are more dispersed and close to the color variables $b^{*}$ and $L^{*}, A w$, vitamin $C$ and moisture. The commercial sample, located in the opposite quadrant, is strongly associated with titratable acidity and firmness. These results are in accordance with those presented in Table 2, indicating that the commercial umbu preserve sample presented higher titratable acidity and firmness.
Additionally, with the CATA descriptive sensory method, consumers were asked to describe the sensory profile of the umbu preserve samples and the test results are presented in table 3 and figure 4. Table 3 indicate that some terms were equally perceived among samples obtained of umbu genotypes, such as sweetness, cloying and sweet aroma and only present significant difference $(p \leq 0.05)$ compared to the commercial preserve; and also that, only one of the attributes, "umbu" aroma, did not differ significantly ( $p>0.05$ ) among all evaluated samples. The term terrible was indicated only in the commercial sample, which was also pointed as the sample with more sourness, astringent, burned aroma and brown dark color. Possibly, higher sourness and astringent may be related to the fact that the commercial preserved present the lowest $\mathrm{pH}$ value and the highest titratable acidity (Table 2). Burned aroma must be related to the processing conditions (higher cooking time due to the fruit process), which was different from the methodology previously standardized and used for

Table 3 - Means for the scores on the CATA (check-all-that-apply) analysis by the consumers $(n=112)$.

\begin{tabular}{|c|c|c|c|c|c|c|c|}
\hline \multirow[t]{2}{*}{ CATA terms } & \multicolumn{7}{|c|}{ 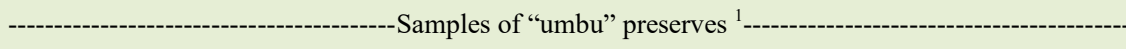 } \\
\hline & Access 37 & Access 44 & BRS 48 & BRS 52 & BRS 55 & BRS 68 & Commercial \\
\hline Attractive color & $0.3 \mathrm{abc}$ & $0.4 \mathrm{a}$ & $0.1 \mathrm{~cd}$ & $0.4 \mathrm{ab}$ & $0.4 \mathrm{a}$ & $0.2 \mathrm{bcd}$ & $0.1 \mathrm{~d}$ \\
\hline Bright & $0.6 \mathrm{ab}$ & $0.6 \mathrm{a}$ & $0.6 a b$ & $0.5 \mathrm{ab}$ & $0.5 \mathrm{ab}$ & $0.4 \mathrm{~b}$ & $0.2 \mathrm{c}$ \\
\hline Brown-yellowish color & $0.4 \mathrm{a}$ & $0.2 b$ & $0.5 \mathrm{a}$ & $0.3 \mathrm{ab}$ & $0.2 \mathrm{bc}$ & $0.4 \mathrm{a}$ & ND \\
\hline Brown-greenish color & $0.2 \mathrm{a}$ & ND & $0.1 \mathrm{ab}$ & ND & ND & $0,1 \mathrm{ab}$ & ND \\
\hline Brown-redish color & $0.1 \mathrm{~cd}$ & $0.4 \mathrm{a}$ & ND & $0.3 \mathrm{~b}$ & $0.5 \mathrm{a}$ & ND & $0.2 \mathrm{bc}$ \\
\hline Brown-dark color & ND & ND & ND & ND & $0.1 \mathrm{~b}$ & ND & $0.7 \mathrm{a}$ \\
\hline Opaque color & $0.1 \mathrm{bc}$ & ND & $0.1 \mathrm{bc}$ & $0.1 \mathrm{bc}$ & $0.1 \mathrm{c}$ & $0.2 b$ & $0.3 \mathrm{c}$ \\
\hline Caramel aroma & $0.1 \mathrm{~b}$ & $0.2 \mathrm{ab}$ & $0.1 \mathrm{~b}$ & $0.3 \mathrm{a}$ & $0.2 \mathrm{ab}$ & $0.1 \mathrm{~b}$ & $0.1 \mathrm{~b}$ \\
\hline "Umbu" aroma ${ }^{\mathrm{NS}}$ & 0.3 & 0.2 & 0.3 & 0.3 & 0.3 & 0.3 & 0.2 \\
\hline Sweet aroma & $0.3 \mathrm{a}$ & $0.3 \mathrm{a}$ & $0.3 \mathrm{a}$ & $0.4 \mathrm{a}$ & $0.4 \mathrm{a}$ & $0.3 \mathrm{a}$ & $0.1 \mathrm{~b}$ \\
\hline Burned aroma & ND & ND & ND & $0.1 \mathrm{~b}$ & $0.1 \mathrm{~b}$ & ND & $0.4 \mathrm{a}$ \\
\hline Sweetness & $0.8 \mathrm{a}$ & $0.8 \mathrm{a}$ & $0.7 \mathrm{a}$ & $0.6 \mathrm{a}$ & $0.6 \mathrm{a}$ & $0.6 \mathrm{a}$ & $0.1 \mathrm{~b}$ \\
\hline Sourness & $0.1 b c$ & $0.1 b c$ & $0.3 b$ & $0.1 b c$ & $0.3 \mathrm{~b}$ & $0.2 b c$ & $0.7 \mathrm{a}$ \\
\hline "Umbu" flavor & $0.5 \mathrm{ab}$ & $0.4 \mathrm{ab}$ & $0.5 \mathrm{a}$ & $0.3 b$ & $0.4 \mathrm{ab}$ & $0.5 \mathrm{ab}$ & $0.4 \mathrm{ab}$ \\
\hline Fibrous residual & $0.2 \mathrm{bcd}$ & $0.1 \mathrm{~cd}$ & $0.3 \mathrm{ab}$ & $0.2 b c$ & $0.3 \mathrm{ab}$ & $0.4 \mathrm{a}$ & $0.1 \mathrm{~d}$ \\
\hline Sticky & $0.2 \mathrm{bc}$ & $0.3 \mathrm{ab}$ & $0.2 \mathrm{bc}$ & $0.2 \mathrm{bc}$ & $0.1 b c$ & $0.4 \mathrm{a}$ & $0.1 \mathrm{c}$ \\
\hline Creamy & $0.2 \mathrm{~cd}$ & $0.5 \mathrm{a}$ & $0.4 \mathrm{ab}$ & $0.4 \mathrm{a}$ & $0.4 \mathrm{ab}$ & $0.3 \mathrm{bc}$ & $0.1 \mathrm{~d}$ \\
\hline Soft & $0.2 \mathrm{de}$ & $0.4 \mathrm{bc}$ & $0.7 \mathrm{a}$ & $0.4 b c$ & $0.5 \mathrm{~b}$ & $0.3 \mathrm{~cd}$ & ND \\
\hline Firm & $0.6 \mathrm{a}$ & $0.2 \mathrm{bcd}$ & $0.1 \mathrm{~d}$ & $0.3 b c$ & $0.2 \mathrm{~cd}$ & $0.4 \mathrm{~b}$ & $0.8 \mathrm{a}$ \\
\hline Astringent & ND & ND & ND & $0.1 \mathrm{~b}$ & $0.1 \mathrm{~b}$ & ND & $0.2 \mathrm{a}$ \\
\hline Tasty & $0.4 \mathrm{a}$ & $0.3 \mathrm{abc}$ & $0.3 \mathrm{abc}$ & $0.3 \mathrm{abc}$ & $0.3 \mathrm{bc}$ & $0.4 \mathrm{ab}$ & $0.2 \mathrm{c}$ \\
\hline Cloying & $0.3 \mathrm{a}$ & $0.3 \mathrm{a}$ & $0.4 \mathrm{a}$ & $0.3 \mathrm{a}$ & $0.4 \mathrm{a}$ & $0.3 \mathrm{ab}$ & $0.1 \mathrm{~b}$ \\
\hline Terrible & ND & ND & ND & ND & ND & ND & $0.3 \mathrm{a}$ \\
\hline
\end{tabular}

${ }^{(1)}$ Means followed by the same letter in the line are not different according to the Cochran's Q test $(p>0.05)$. ND $=$ not detected; NS $=$ not significant. 


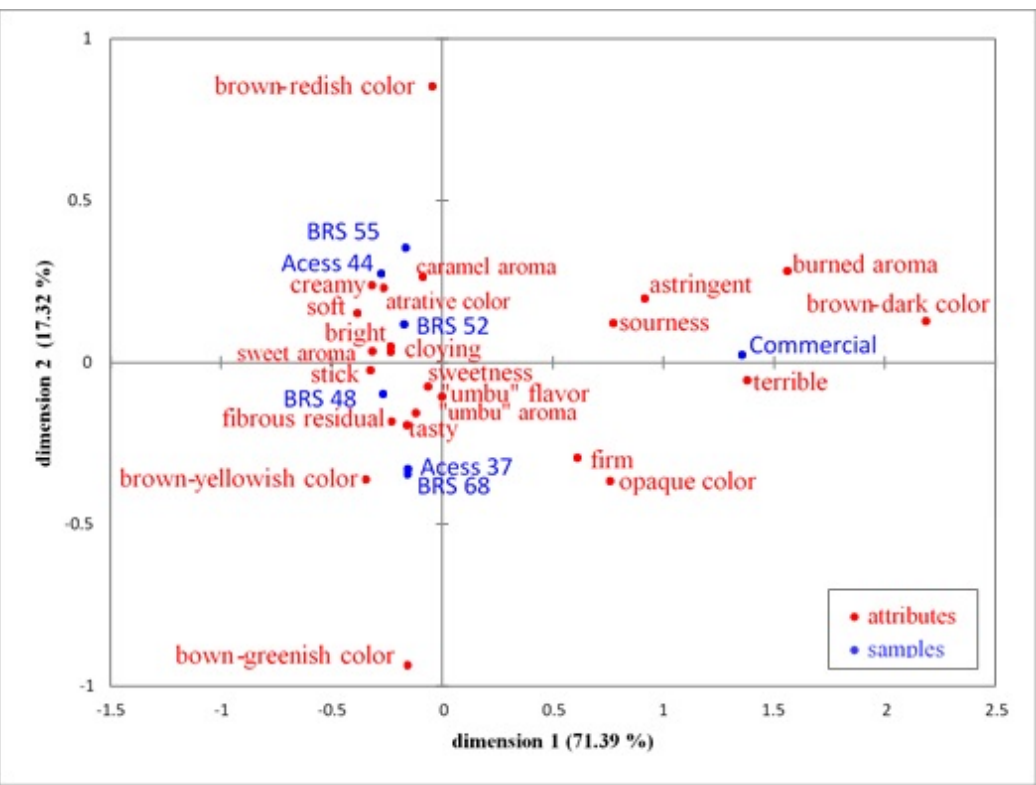

Figure 4 - Correspondence Analysis obtained by the sum of the cited terms of the CATA evalulation for the samples of the umbu preserves.

the elaboration of the preserves from the different genotypes in this study (the pulp was obtained in the pulper and the heat was applied only to concentrate the product until achieving $75{ }^{\circ}$ Brix of soluble solids). Therefore, the terms brown-yellowish color, brown-greenish color and soft was not detected in the commercial sample.

These results may be related to those of the instrumental analysis of color and texture (Table 2), showing that the commercial samples presented lower value of $\mathrm{L}^{*}, \mathrm{~b}^{*}$ and higher firmness. The presence of brown-greenish color was only observed in the preserves from the Access 37, BRS 48 and BRS 68 , and the brown-redish color was not detected in the preserves from the BRS 48 and BRS 68. Results obtained in the color instrumental analysis, presented on, which show that these three samples (Acess 37, BRS 48 and BRS 68) presented the lowest values of $\mathrm{a}^{*}$, indicating a higher incidence of green color.

According to the Correspondence Analysis, obtained with the sum of the CATA terms (Figure 4), it is possible to observe that the samples were divided into three groups of similarity in relation to the sensorial profile. The commercial sample that makes a single group, located on the positive side of the first and second main components, is described by the terms sourness, astringent, burned aroma, brown- dark color and the emotion term terrible. It is possible to infer that some of these cited characteristics may be undesirables in the umbu preserve for the consumers. Possiblty for this reason, the group formed by the majority of the consumers, were localized in relation to the PC 1 of the MDPREF (Figure 2B) in the opposite position of the commercial preserve and next to the samples obtained by the genotypes Acess 44, Acess 37, BRS 52 and BRS 55,that were the products of their preference. These formulations, except the preserve obtained with the Acess 37, formed a second group in the CA, located at the negative values of the first and positive values of the second component, described mainly by the terms attractive color, brown-redish color, caramel aroma and creamy. Therefore, the third group, composed of the samples from Access 37, BRS 48 and BRS 68 , located at negative values of the first and second components in the CA, is described mainly as tasty and brown-yellowish color.

\section{CONCLUSION}

The umbu preserves obtained from the umbu genotypes showed different physico-chemical composition and CATA indicated that the umbu preserves were segmented in distinct groups of sensory profile. 
The presence of the attributes astringent, opaque color, sourness, burned aroma and browndark color were linked with the rejection of the product. The genotypes Acess 37, Acess 44, BRS 52 and BRS 55 generated the umbu preserves of greater preference by the consumers. Among these, Acess 37 stands out, showed the more adequate firmness to the product and satisfactory syneresis, being more appropriate for the production to this type of preserves (in bars).

\section{ACKNOWLEDGMENTS}

This study was financed in part by the Coordenação de Aperfeiçoamento de Pessoal de Nível Superior - Brasil (CAPES) - Finance Code 001, and by the Brazilian Agricultural Reseach Coorporation (Embrapa) - project SEG 03.13.06.018.00.00.

\section{BIOTHICS \\ AND \\ COMMITTEE APROVAL}

\section{BIOSECURITY}

The sensorial analyses procedures were approved by the Research Ethics Committee (CEP/UNIVASF protocol $\mathrm{N}^{\circ}$. 1.520.838/2016 and CAAE 41663815.4.0000.5196), in compliance with Resolution 466/12, of the National Health Council, Brazil.

\section{DECLARATION OF CONFLICTS OF INTERESTS}

The authors declared no potential conflicts of interest with respect to the research, authorship, and/or publication of this article.

\section{AUTHORS' CONTRIBUTIONS}

The authors contributed equally to the manuscript.

\section{REFERENCES}

AGUDELO, A. et al. Formulating fruit fillings. Freezing and baking stability of a tapioca starch-pectin mixture model. Food Hydrocolloids, v.40, p.203-213, 2014. Available from: <https:// doi.org/10.1016/j.foodhyd.2014.02.020>. Accessed: May, 23, 2018. doi: 10.1016/j.foodhyd.2014.02.020.

ALMEIDA, M. M. B. et al. Bioactive compound and antioxidant activity of fresh exotic fruits from Northeastern Brazil. Food Research International, v.44, n.7, p.2155-2159, 2011. Available from: <https://doi.org/10.1016/j.foodres.2011.03.051>. Accessed: Mar. 21, 2017. doi: 10.1016/j.foodres.2011.03.051.

ARAUJO, F. P. de. Sistema de produção: desenvolvimento de uma fruticultura de sequeiro para o fortalecimento da agricultura de base familiar. In: SEMANA ITINERANTE PROJETO LAGO DE SOBRADINHO, 1., 2014, Petrolina. Palestras... Petrolina, PE: Embrapa, 2014. Available from: $<$ http://ainfo.cnptia.embrapa. br/digital/bitstream/item/123261/1/Pinheiro-cpatsa-2014.pdf $>$. Accessed: Mar. 21, 2017.

ARAUJO, F. P. de et al. Umbuzeiro: alternativas de manejo sustentável e aproveitamento em Áreas de produtores familiares em Uauá, BA. In: DIAS, T.; ALMEIDA, J. S. S. E.; UDRY, M. C. F. V. (Ed.). Diálogos de saberes: relatos da Embrapa. Brasília, DF: Embrapa, 2016. cap.9. p.363-378. Available from: $<$ https://ainfo.cnptia.embrapa.br/digital/bitstream/item/171481/1/ Cap.9.Umbuzeiro-alternativas.pdf>. Accessed: Mar. 21, 2017.

ARES, G. et al. Penalty analysis based on CATA questions to identify drivers of liking and directions for product reformulation. Food Quality and Preference, v.32, p.65-76, 2014. Available from: $<$ http://dx.doi.org/10.1016/j.foodqual.2013.05.014>. Accessed: Jun. 26, 2018. doi: 10.1016/j.foodqual.2013.05.014.

ASSOCIATION OF OFFICIAL ANALYTICAL CHEMISTS [AOAC]. Official Methods of the Association of Official Analytical Chemists. 19 ed. Washington, 2012.

BIASOTO, A. C. T. et al. Acceptability and preference drivers of red wines produced from Vitis labrusca and hybrid grapes. Food Research International, v.62, p.456-466, 2014. Available from: $<$ https://doi.org/10.1016/j.foodres.2014.03.052>. Accessed: Jun. 26, 2018. doi: 10.1016/j.foodres.2014.03.052.

CROPOTOVA, J. et al. Effect of freezing on microstructure and degree of syneresis in differently formulated fruit fillings. Food Chemistry, v.195, p.71-78, 2016. Available from: <https://doi. org/10.1016/j.foodchem.2015.03.056>. Accessed: May, 23, 2018. doi: $10.1016 /$ j.foodchem.2015.03.056.

DIAS, M. V. et al. Estudo de variáveis de processamento para produção de doce em massa da casca do maracujá (Passiflora edulis f. flavicarpa). Ciência e Tecnologia de Alimentos, v.31, n.1, p.65-71, 2011. Available from: <https://doi.org/10.1590/ S0101-20612011000100008>. Accessed: Jun. 14, 2018. doi: 10.1590/S0101-20612011000100008.

FENNEMA, O. R. et al. Química de alimentos de Fennema. Artmed, 4ed., 2010, 900p.

FERREIRA, J. C. et al. Análise sensorial da polpa de umbu submetida a congelamento inicial em temperaturas cruiogênicas e armazenadas em câmaras frigoríficas. Revista Brasileira de Produtos Agroindustriais, v.2, n.1, p.7-17, 2010. Available from: $<\mathrm{http} / /$ www. deag.ufcg.edu.br/rbpa/rev21/Art212.pdf>. Accessed: Jan. 19, 2017.

FISZMAN, S. M.; DURÁN, L. Effects of fruit pulp and sucrose on the compression response of different polysaccharides gel systems. Carbohydrate Polymers, v.17, p.11-17, 1992. Available from: $<$ https://doi.org/10.1016/0144-8617(92)90018-L>. Accessed: May, 23, 2018. doi: 10.1016/0144-8617(92)90018-L.

GALVÃO M. S. et al. Volatile compounds and descriptive odor attributes in umbu (Spondias tuberosa) fruits during maturation. Food Research International, v.44, n. 7, p.1919-1926, 2011. Available from: <https://doi.org/10.1016/j.foodres.2011.01.020>. Accessed: May, 23, 2018. doi: 10.1016/j.foodres.2011.01.020.

GAVA, A. J. et al. Tecnologia de Alimentos: princípios e aplicações. São Paulo: Nobel; 2009.

GODOY R. C. B. et al. Estudo da composição físico-química e aceitação de bananadas comerciais por meio de analise multivariada. Revista Instituto Adolfo Lutz, v.68, n.3, p.373-80, 2009. Available from: <http://periodicos.ses.sp.bvs.br/pdf/rial/ v68n3/v68n3a08.pdf>. Accessed: Sep. 18, 2018.

IBGE. Produção da extração vegetal e da silvicultura - 2018. Available from: <https://sidra.ibge.gov.br/pesquisa/pevs/quadros/ brasil/2018>. Accessed: Dec. 18, 2019.

Ciência Rural, v.51, n.2, 2021. 
JACKIX, M. H. Doces, geléias e frutas em calda. São Paulo: Ícone, 1988. p.85-158.

MACFIE, H. J. H. et al. Designs to balance the effect of order of presentation and first-order carry-order effects in hall tests. Journal Sensory Studies, v.4, p.129-148, 1989. Available from: $<$ https://www.academia.edu/29374131/Designs to Balance the Effect_of_Order_of_Presentation_and_First_Order_Carry_Over_ Effects_in_Hall_Tests $>$. Accessed: Oct. 26, 2017.

MACFIE, H. J. H.; THOMSON, D.M. H. Preference mapping and multidimensional scaling. In J. R. Piggott (Ed.). Sensory Analysis of Foods. London: Elsevier Applied Science, 1988. p.380-409.

MACHADO, C. de F.; FONSECA, N. Variabilidade de características físicas e químicas de frutos de germoplasmas de umbuzeiros (Spondias tuberosa). In:Congresso Brasileiro de Fruticultra, 21., 2010, Natal. Frutas: saúde, inovação e responsabilidade: anais. Natal: Sociedade Brasileira de Fruticultura, 2010. Available from: <http://ainfo.cnptia.embrapa.br/digital/ bitstream/item/36173/1/ID27156pdf1433.pdf $>$. Accessed: May, $23,2018$.

MARTINS, M. L. A. et al. Características de doce em massa de umbu verde e maduro e aceitação pelos consumidores. Pesquisa Agropecuária Brasileira, v.42, n.9, p.1329-1333, 2007. Available from: <https://doi.org/10.1590/S0100204X2007000900015>. Accessed: Jun. 14, 2018. doi: 10.1590/ S0100-204X2007000900015.

MARTINS, M. L. A. et al. Alterações físico-químicas e microbiológicas durante o armazenamento de doces de umbu (Spondias tuberosa Arr. Câmara) verde e maduro. Ciência e Tecnologia de Alimentos, v.30, n.1, p.60-67, 2010. Available from: $<$ https://doi.org/10.1590/S0101-20612010005000004>. Accessed: Jun. 14, 2018. doi: 10.1590/S0101-20612010005000004.

McREADY, R. M.; McCOMB, E. A. Extraction and determination of total pectic materials in fruits. Analytical Chemistry, v. 24 p.1986-1988, 1952.

MENEZES, A. A. et al. Caracterização física e físico-química de diferentes formulações de doce de goiaba (Psidium guajava L.) da cultivar Pedro Sato. Ciência e Tecnologia de Alimentos, v.29, n.3, p.618-625, 2009. Available from: $<$ https://doi.org/10.1590/S0101-
20612009000300025>. Accessed: Jun. 14, 2018. doi: 10.1590/ S0101-20612009000300025.

OLIVEIRA, E. N. A. de et al. Tecnologia e processamento de frutas: doces, geleias e compotas. IFRN: Natal, 2018. 316p. Available from: $<$ https://memoria.ifrn.edu.br/bitstream/handle/1044/1664/ Tec.\%20e\%20Proc.\%20de\%20Fruta\%20s\%20-\%20E-Book. pdf?sequence=1\&isAllowed=y>. Accessed: Sept. 14, 2019

OLIVEIRA, V. R.et al. Umbuzeiro: avanços e perspectivas. Brasília, DF: Embrapa, 2016. cap.3. p.81-116.

PAULA, B. de et al. Produção e caracterização físico-química de fermentado de umbu. Ciência Rural, v.42, n.9, p.16881693, 2012. Available from: <https://doi.org/10.1590/S010384782012000900027>. Accessed: May, 28, 2019. doi: 10.1590/ S0103-84782012000900027.

RUFINO, M. do S. M. et al. Bioactive compounds and antioxidant capacities of 18 non-traditional tropical fruits from Brazil. Food Chemistry, v.121, n.4, p.996-1002, 2010. Available from: $<$ https:// doi.org/10.1016/j.foodchem.2010.01.037>. Accessed: Jan. 19, 2017. doi: 10.1016/j.foodchem.2010.01.037.

SANTOS, C. A. F. et al. Variabilidade genética do umbuzeiro no Semi-Árido brasileiro, por meio de marcadores AFLP Pesquisa Agropecuária Brasileira, v.43, n8, p.1037-1043, 2008. Available from: <https://doi.org/10.1590/S0100204X2008000800013>. Accessed: Sep. 19, 2017. doi: 10.1590/ S0100-204X2008000800013.

SANTOS, C.A.F. et al. Umbuzeiro: pesquisas, potenciais e desafios. In: ROMÃO, R.R.; RAMOS, S.R.R. (Org.). Recursos genéticos vegetais no Estado da Bahia. Feira de Santana: UEFS, 2005. p.69-81. Available from: <http://ainfo.cnptia.embrapa.br/ digital/bitstream/item/196678/1/Umbuzeiro-Pesquisas-Potenciaise-desafios.pdf $>$. Accessed: Jun. 18, 2017.

STROHECKER, R.; HENNING, H.M. Analisis de vitaminas: métodos comprobados. Madrid: Paz Montalvo, 1967. 428p.

WICKLUND, T. et al. Antioxidant capacity and colour of strawberry jam as influenced by cultivar and storage conditions. Lebensmittel Wissenschaft und technology, London, v.38, p.387-391, 2005. 